レーザー解説

\title{
重力波検出用LD励起YAGレーザーの周波数安定化
}

\author{
植田憲- - 上原昇 ${ }^{*}$
}

（1993年 7 月 14 日 受理）

\section{Frequency Stabilization of LD-pumped YAG Lasers for Gravitational Wave Detection}

\author{
Ken-ichi UEDA* and Noboru UEHARA*
}

(Received July 14, 1993)

\begin{abstract}
Frequency stabilized solid state lasers related to the gravitaional wave detection are reviewed. In order to detect gravitaional waves from super novae or a coallescence binary stars, the sensitivity should be higher than $10^{-19}$ to $10^{-22}$. A large interferometer is a possible solution if we can develop a stable light source, mode cleaner optics, free-mass optical cavity, antivibration systems operating at their quantum or theoretical limits. We measured the FM-noise at the shot noise limit by means of LD-pumped YAG lasers. The tracking capability was examined by the beatnote spectrum of $193 \mathrm{mHz}$ directly. The measured spectrum and Allan root variance showed that the beat line width is determined by the thermal drift of reference cavities in two-laser and two-cavity mode. We report the present status of technological development of ultra-stabilized lasers, ultra-high quality optics, and high power lasers for gravitational wave measurements.
\end{abstract}

Key Words: YAG lasers, LD-pumping, Frequency stabilization, Gravitaional wave, Optical cavity

\section{1.はじめに}

一般相対性理論によってアインシュタインが 予測した重力波を直接計測し，それを通じて， ダイナミックな宇宙像や真の宇宙の大きさを決 定しょうとする試みが進められている。重力波 は4重極放射された横波であり，XY平面に垂直 に入射した重力波は，X軸が伸びるならY軸が 縮むというように空間を変形させる。マイケル ソン干渉計の反射鏡を自由質量としておけば, 重力波の入射によって生じる両腕の長さを, 光
学的に計測できる。重力波アンテナで鏡が吊ら れているのは, 地面振動の防振という意味もあ るが，より基本的には鏡を慣性系における自由 質量として，空間のひずみを測定するためであ る。重力波検出が代表する純学術的研究の特長 は，ある部分の困難性を別の部分の改良で分担 解決するようなトレードオフがないことである。 レーザーの安定化, 光学素子技術, 干渉計の制 御，防振技術，すべてにわたって，理論限界に 到達して初めて, 重力波は検出可能なレベルと なる。一見，非現実的に見える厳しい要求であ

*電気通信大学レーザー極限技術研究センター（テ182 東京都調布市調布ケ丘1-5-1)

* Institute for Laser Science, University of Electro-Communications (1-5-1 Chofugaoka, Chofu, Tokyo 182 Japan) 
る。しかし，現実に世界で，そしてわが国でも このような課題に正面から取り組んでいる有能 な研究者がいることも事実であり，わが国でい うハイテクとは違った先端的科学技術研究が存 在する。とりわけ，米国，欧州では，100億-250 億円といった予算のプロジェクトが認められ， 建設が開始されている。本論文では, わが国で 進行中の重力波アンテナ開発に関係するレーザー の周波数安定化技術の現状について報告する。 Arレーザーを光源とする諸外国と違って，わが 国の計画ではLD励起固体レーザーを光源に採 用する。 $\mathrm{LD}$ (半導体レーザー) 励起固体レーザー はフリーランニングモードにおける周波数雑音 が他のレーザーに比べて際だって少ない。さら に, LDや新しい固体レーザー材料の飛躍的な 進歩が期待されるので, 重力波アンテナ用光源 である周波数安定化レーザーとして, LD励起 固体レーザーを採用した。本論文で紹介するよ うにこのような選択が正しかったことをこれ までの研究成果は示している。

\section{2. 重力波検出用干渉計が要求するもの}

重力波天文学, 重力波検出のためのアンテナ の開発1) は, その技術的困難さからいって, こ れまでわが国で行われた技術的研究の最右翼で ある。超新星爆発などに伴う重力波は存在はほ ぼ確証されているものの，いまだ直接的な観測 の例はない。なぜなら，重力波は物質と相互作 用をする力がきわめて弱いので, 測定できない からである。実際, 重力波アンテナが観測しよ うとする“重力波による空間の歪み”は, Fig. 1 にみられるように地球と太陽の間の距離が水素 原子 1 コ分だけ伸びるだけの量でしかない。重 カ波アンテナにはもっとも微量な変位を測定で きるレーザー干渉計）を用いる。当然, 干渉計 を構成しているミラーは予想される重力波の周 波数において, 想像を絶する精度で静止してお り，同時に干渉計を構成するように高精度にア ライメント・コントロールされなければならな い。将来計画で想定しているアンテナは長さ $150 \mathrm{~km}$ に相当する光学アーム長を持ち, それが
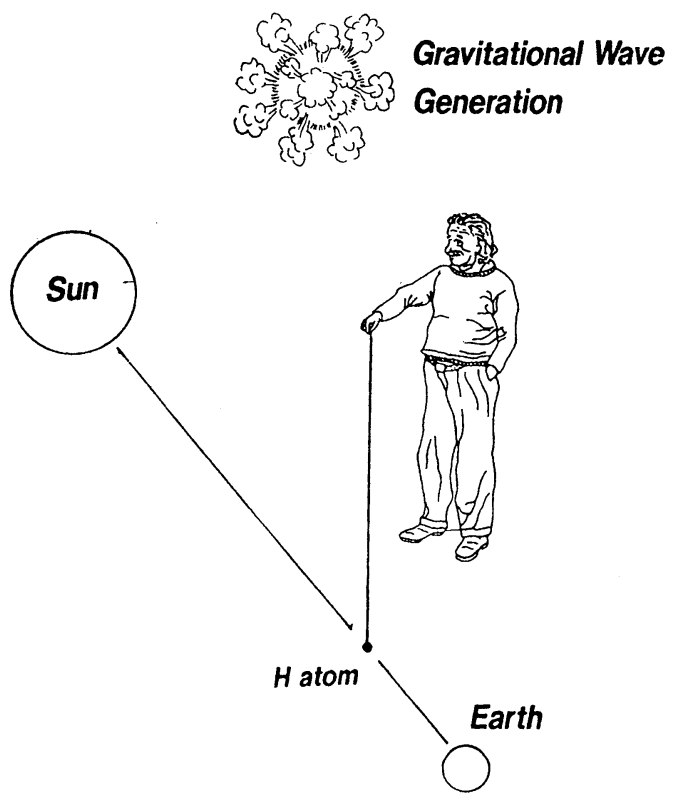

Fig. 1 The sensitivity for gravitaional wave detection is relatively equivalent to the detection of a single hydrogen atom in the space between the sun and the earth.

$10^{-7}$ オングストロームだけ変化するのを測定し ようとする。同時に干渉計の光源の強度，周波 数に変動があってはならず, 強度の安定度で, $10^{-9} / \sqrt{\mathrm{Hz}}$, 周波数の安定度で $10^{-21} / \sqrt{\mathrm{Hz}}$ が “原理的に”要求される。このような安定度は $1 \mathrm{~kW}$ のレーザー出力が持っている量子雑音, す なわち本質的に光子の集団が不確定性関係で決 められた変動をすることに起因する雑音を意味 しており, それ以下の強度の光では達成するこ とが原理的にできない。100 Wの単一縦横モー ドの発振をさせることが困難な現在のレーザー 技術に比べて, いかに遠大な目標であるか, 容 易に理解することができるだろう。他の部分の 技術に要求される水準も同様である。ちなみに, 欧州で開発されている干渉計のミラー防振系の スケッチをFig. 2に示す。高さ11.6メートルに 達するスーパー防振系は, 7段の防振装置を重

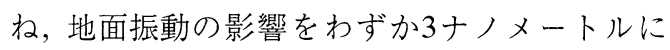
まで減衰させようという野心的なものである。 


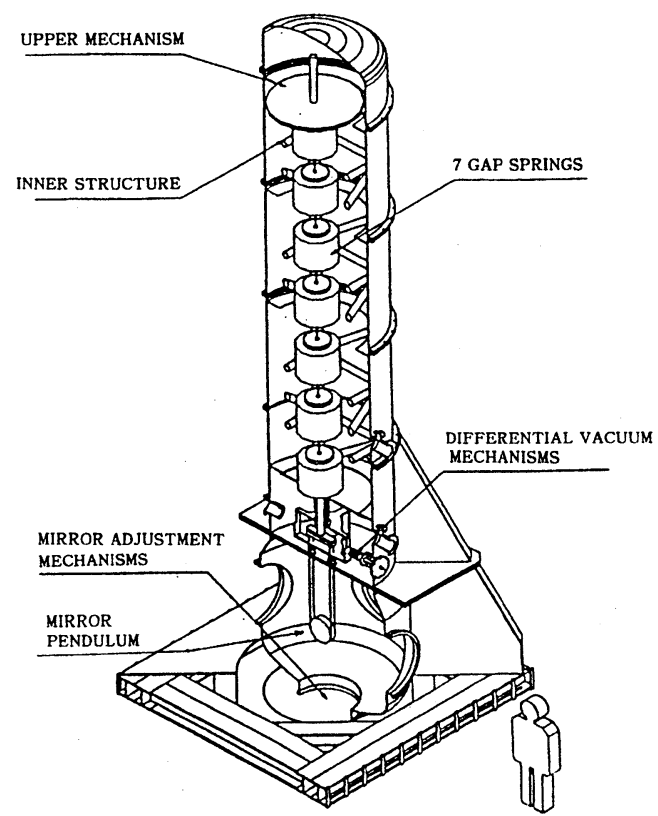

Fig. 2 Anti-vibration and mirror control tower in European VIRGO project.

\section{3. 周波数安定化レーザー}

レーザーは電波のように位相の揃った干渉性 のよい光を発生させることが“できる”。しか し，現実には電波のように波としての性質を利 用した応用は科学実験を除いて広く普及してい るとは云いがたい。現状は，“強力な光”， “どこまでも平行な光”, “時間的に短い光パル ス”など光の性質の内のほんの一部を利用して いるにすぎない。これは，“光の純度”が理想 的ではないために，限られた範囲の干渉性しか 使えないことに起因している。光の純度はビー ムに含まれている光子のエネルギーのばらつき で決まり, 光エネルギーが $\mathrm{E}=\mathrm{h} \nu$ で表されるこ とから，レーザー周波数の純度を意味している。 レーザーの周波数を安定化させ, 光としての純 度を向上させることは，レーザーの発明以来, 基本的な課題であった。

3. 1 LD励起YAGレーザーの周波数安定化 レーザーの周波数を極限的に安定化させるに
は，周波数を測定し，基準の周波数からずれれ ば，フィードバックをかけてそれを補正すれば よい。しかし，極限的な安定度を求める場合， 他により精度の高い基準がない以上，自分自身 を基準とする以外にない。すなわち，高フィネ ス光共振器に光を蓄積し，“時間積分した自ら の過去”に，”現在の自分”を一致させるよう にして安定化をさせる。光共振器は光をため込 んでいる時間, 光信号に対する積分器として働く ので, 光共振器の応答時間よりも短い時間の変 化成分は，互いに打ち消しあって消滅してしま う。このため, 自分を基準としながらも，自分 よりもさらに安定な光信号を発生させるように レーザーを調整することができるようになる。 したがって，”物差し”となっている光共振器 の性能は超高性能でなくてはならない。

周波数安定化を行うレーザーの共振器は, 当 然のことながら単一横モードで単一周波数発振 をするものでなくてはならない。端面励起LD による励起によって，単一横モード発振は容易 になったが，縦モードを単一化するためには， Fig. 3のようなリング共振器またはツイストモー ド共振器で構成されたレーザーが適している。 このような共振器では空間的ホールバーニング を起こさないので，単一モード発振が容易に実 現される。ファラデー効果を内蔵した単一方向 リング共振器や，1／4波長板を挿入したツイス トモード共振器 ${ }^{3)}$ で, 参照共振器からの戻り光
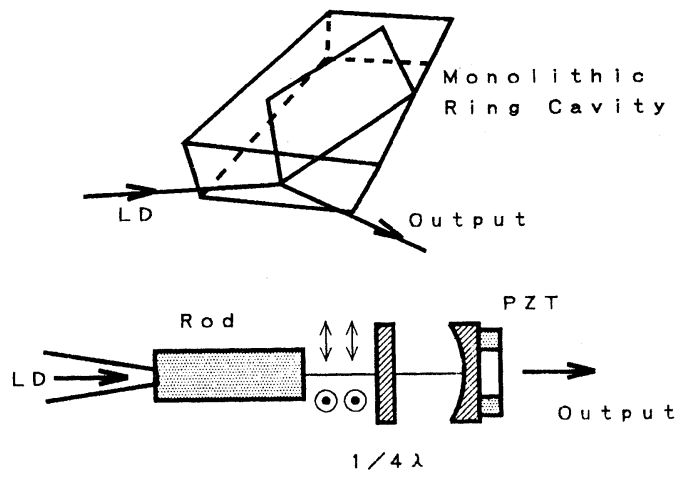

Fig. 3 Resonators for frequency stabilized lasers. 
の影響を排除している。結晶の全反射による共 振器を構成するモノリシック共振器は, 非平, 面 型共振器に設計され, 外部磁界を印加して, YAG結晶自体のファラデー効果で単一方向リ ング共振器となる。偏光固有モードの発振であ るために, 外部共振器からの光フィードバック の影響を受けにくい特長がある。結晶につけら れたPZT素子がYAG結晶を变形させて, 高速 な周波数变調を可能にしている。

周波数安定化のためには, 光共振器の長さを 変調するPZT素子, 外部で周波数シフトさせる 音響光学素子 $(\mathrm{AOM})$, 電気光学素子 $(\mathrm{EOM})$ を 利用する。AOMでは回折された光の周波数に は，印加した超音波の周波数成分がドプラー効 果で加算されるので，光周波数をシフトさせる ことができる。同時に, 反対方向に入射した光 に，ドプラー効果がさらに追加されるので，効 果的な一方向性フィルターとして作用する。同 様のドプラーシフトは光学的距離を電気的に制 御できるEOMでも発生し, 低周波から高周波 まで，PZT，AOM，EOMを各々利用して，その バンド幅に応じて周波数制御を行う。

周波数安定化にはDrever-Hall法 ${ }^{4)}$ 用いて, 出力最大の点に周波数をロックする。外部から の光雑音の影響を受けないようにリング共振器 型のレーザー5)を使用した。EOMで20MHzの 周波数で位相変調をかけたレーザー光をモード整 合させて参照共振器に入射させ, 共振器からの 反射光を検出, DBM (Double Balanced Mixer) で復調する。周波数安定化されたLD励起 $\mathrm{YAG}$ 。 レーザーの周波数雑音スペクトルをFig. 4に示 した。フィードバック回路のエラー信号で見る 限り，周波数雑音はショット雑音に達している。 レーザーの周波数が $3 \times 10^{14} \mathrm{~Hz} ゙$ あることを思 い出せば，周波数安定の程度が理解できるだろ う。これらの詳細については, 別途, 論文 ${ }^{6)}$ 参照されたい。

3.2 同じ共振器にロックした2台のレーザー のビート周波数の測定

2台のレーザーを同時に安定化させれば，電

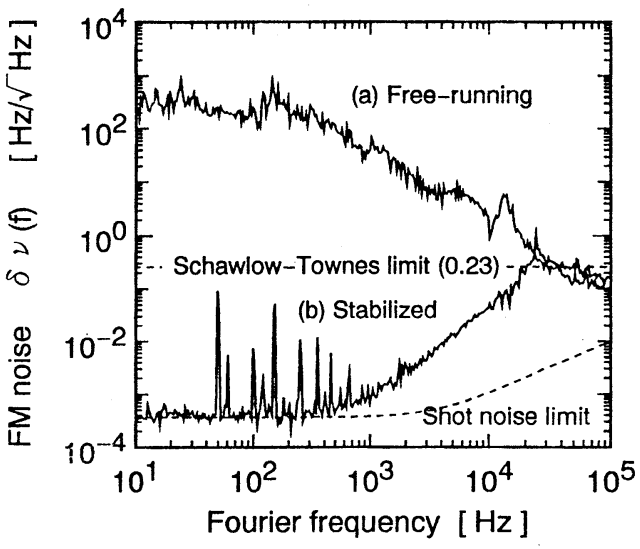

Fig. 4 FM noise spectra of the LD-pumped YAG laser. Upper trace : free running mode, lower trace : stabilized mode.

波と同じようにレーザー光同士のビートを観測 することができる。ここでは2台のレーザーは 共に同じ参照共振器にロックされているが, まっ たく同じ周波数でなく, 隣接する異なった縦モ一 ドに各々ロックされている。各々別個に安定化 を行うために，位相変調の周波数も $15,20 \mathrm{MHz}$ と分けられており, 参照共振器の長さの変動 $1 \mathrm{~nm}$ あたり $3.6 \mathrm{~Hz}$ だビート周波数が変化して，共 振器長さの極微の変化も反映するようにした。 測定された光ビートのスペクトル幅はFig. 5の 通りで，193mHz $\mathrm{mz}^{7}$ のビート線幅が観測された。 これは現時点で観測された固体レーザーの周波 数ビートでもっとも狭い線幅である。スペクト

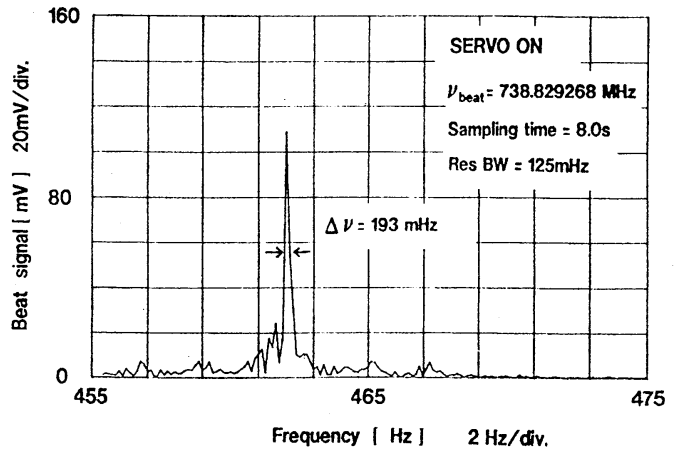

Fig. 5 Beat spectrum for one-laser locked to onecavity. 
ラム・アナライザの分解能が $125 \mathrm{mHz}$ あ゙あこ とを考慮すると, 実際の線幅はもっと狭い。

念のために，ビート線幅の測定に用いた各種 の計測器の雑音成分を測定した。中でも，周波 数シンセサイザ $(\mathrm{SSG})$ の周波数安定度は測定精 度に大きく影響を与える。なぜなら, ビート周 波数を与える参照共振器のFSR (Free Spectrum Range) は739MHzと高周波であるため，1 Hz以 下の分解能を得ることが不可能なので, $739 \mathrm{MHz}$ の電気信号をSSGで作り出し，レーザーのビー 卜信号と混合してそのビートを取って，低周波 のスペクトラム・アナライザで高分解能に検出 するミックスダウン法を採用せざるを得ないか らである。したがって, SSGの基準周波数が変 動すると, 計測したビート信号は連動して変動 する。739 MHzからミックスダウンして100 mHz の分解能を保証するにはSSGの安定度が $10^{-10}$ 以上なければ精度が保証できない。実際に測定 されたSSGの周波数安定度を安定化のためのウォー ムアップ時間の関数として測定した結果がFig. 6

Frequency stability of HP8656B (1) measurement time $T_{m}=120 \mathrm{~s}$

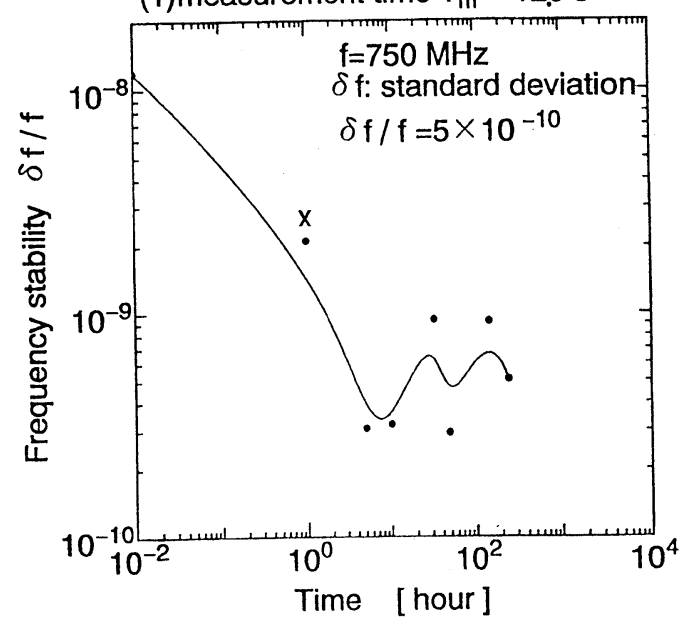

Fig. 6 Frequency stability of frequency synthesizers used in this measurement. Open circles show the measured noise of synthesized signal generators, crossed points show the measured laser beat by mix-down method using a SSG.
で，測定されたビート線幅はすべてSSGから発 生している雑音であることが分かった。

3.3 独立の共振器にロックしたレーザー間 のビート計測

同じ共振器に周波数ロックしたレーザーのビー 卜は，周波数安定化の追随特性を調べるために は好適で, 重力波検出のように干渉計に対する 相対的安定度が必要な応用では十分である。し かし, 参照共振器の変動成分はビート周波数に 敏感に反映しないので，2つの独立な共振器に ロックして，周波数ビートを観測した。今回は 99. 999\%ミラーを用いたので, 参照共振器はす べて真空中に配置して，音響雑音を防止した。 結果はFig. 7に示した通りで，ビート線幅とし て16 Hz ${ }^{8)}$ を得た。アラン分散の計測からも $19 \mathrm{~Hz}$ の結果があり，確実な值である。Fig. 8のよう なドリフトが観測され, 共振器にレーザー光が 入射すると, 光学薄膜が加熱され, 厚みが変化 する効果や, 共振器そのものが熱平衡に達する 時定数との関係を調べている。現状のビート線 幅は熱的ドリフトで説明できる量なので, 今後, 参照共振器の温度安定化によって, 周波数安定 度は向上させることができる。

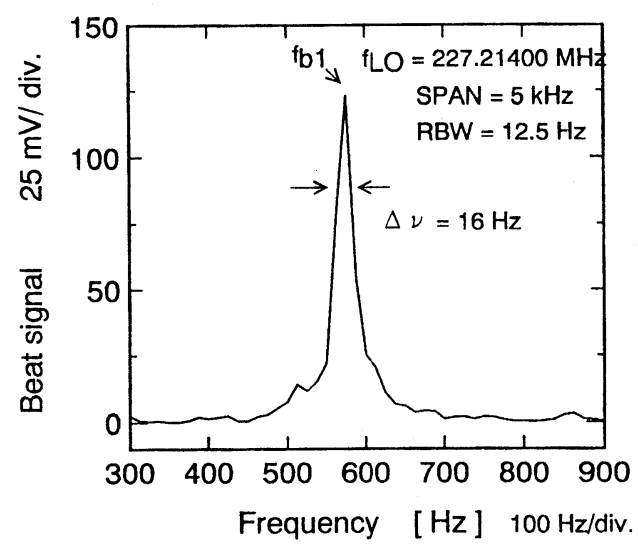

Fig. 7 Measured beat line spectrum for two-lasers locked to two-cavities individually. 


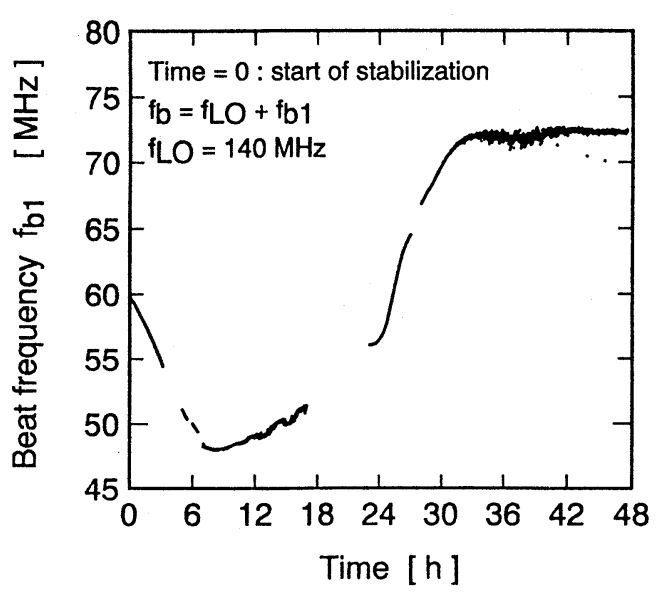

Fig. 8 Drift of beat frequency of two-lasers locked to two-cavities system.

\section{4. 超高性能光共振器の現状}

さて，先に周波数のズレを測定するのは “物 差し”である参照共振器の性能に大きく依存し ていることを指摘した。それでは高性能光共振 器はどこまで進歩しているのだろうか。重力波 検出に関係した現代の光学技術はFig. 9のよう な透過スペクトルを持つ光共振器を可能にした。 Fig. 9の透過特性を生み出したミラーはイオン ビーム蒸着法で製作され，共振器長が $20 \mathrm{~cm}$ であ

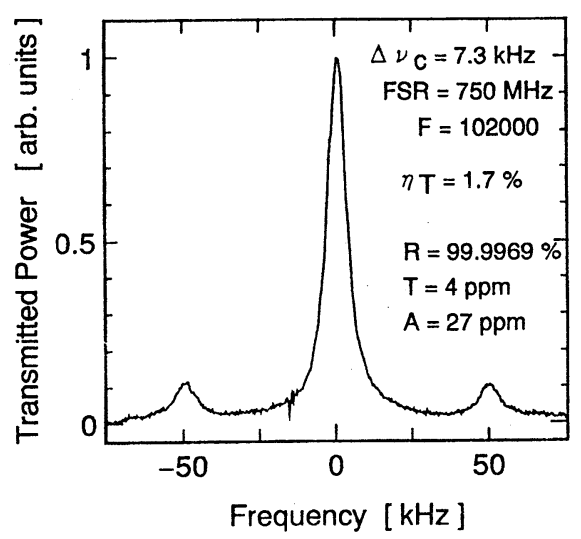

Fig. 9 Transmission spectrum of the Fabry-Perot cavity constructed by ultra-high quality mirrors.
る。内部に何も含まない2枚のミラーを対向さ せて固定した光共振器は, 透過帯域がわずか $7.3 \mathrm{kHz}$ という超狭帯域のファブリ・ペロー(FP) 共振器となっている。測定されたフィネスは 102,000程度である。ここで，フィネスとは光 の選択性を表現する量

$$
\tau=\frac{\pi \sqrt{R}}{1-R}
$$

でミラーの反射率 $R$ の関数である。従来の常識 では, FP共振器のフィネスは普通30程度, 特別 に作ったとしても200程度が限界であった。し かし，最先端の技術を使ったミラーはこのよう な常識を完全に反故にしてしまった。Fig. 10に 示した光共振器の周波数応答からの測定は, ミ ラー掃引を含まないのでより正確である。99.99\% ミラーを用いた場合, 驚くべきことに光共振器 に入射した光入力の内 $83 \%$ は損失を受けること なく, 反対側のミラーから出力した。測定され た損失 (吸収十散乱) はわずかに $12 \mathrm{ppm}$ である。 世界では損失わずか $1.6 \mathrm{ppm}$, フィネス $1.9 \times 10^{6}$ という驚異的な性能の共振器9)も製作された。 このように従来の常識からかけ離れた光共振器 が存在するようになると, 改めて超高性能光共 振器があれば, どのようなことが可能になるの かを再検討する必要が出てくる。

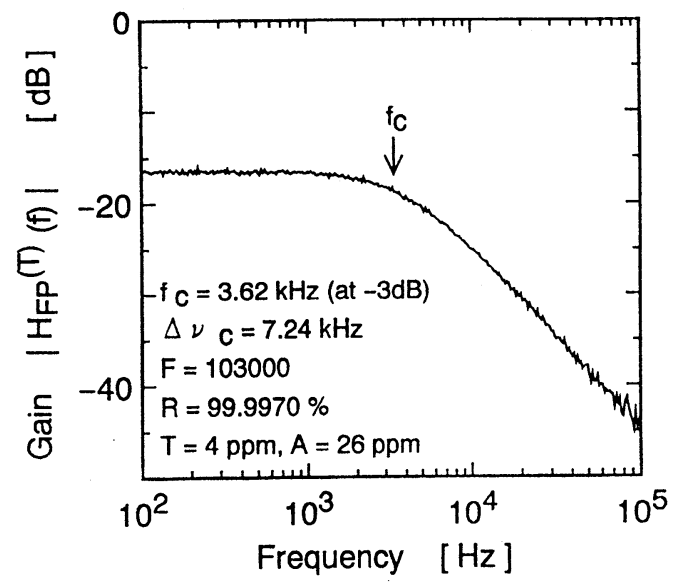

Fig. 10 Measurement of mirror parameters by frequency responce of optical resonator. 
改めて超高性能光共振器の能力について考え てみよう。フィネスが100万に達するような光 共振器では, (1)光共振器の寿命が原子の寿命を 上回るくらい長くなる。すなわち光エネルギー を蓄積する寿命はミリ秒にも達する。また(2)共 振器内の光強度はフィネス倍になることから, 弱いレーザーを共振器に同調させれば，それは 直ちに高強度の光の場を作り出すことになる。 実際，レーザー周波数の安定化の実験ではミリ ワット級出力のレーザーで, 単位面積あたり 30 メガワットの共振器内光強度に達している。光 共振器がエネルギーを蓄積する能力は, 以下の ように考えると, その重要性がよく分かる。光 は常に秒速30万キロメートルの速度で伝播して おり, 減速したり, 静止させたりすることが不 可能な存在である。このため, これまでの方法 はすべて原子や分子の内部エネルギーに変換し てエネルギーを蓄積しており, 光エネルギーの 形で蓄積することはなかった。また, 光共振器 はすべてを人間が作りだし，制御できるもので, 光エネルギーそのままの形で蓄積する点は特筆 すべきことだろう。結果として, 超高性能の光 学素子は人工的な原子を生み出すに至ったので ある。

\section{5. 周波数安定化レーザーと超高性能光学素 子の結合}

これまで述べてきた周波数安定化技術と超高 性能光学素子の技術を結合すれば，どのような 新しい光技術を考えることができるのだろうか。 例をあげて説明してみよう。

\section{1 コヒーレント加算}

高精度に周波数安定化させたレーザー光を用 いれば, 光のコヒーレントな性質によって, 1本のレーザービームを2本に分けたのと同じよ うに，2つのレーザーのビームは電界的に加算 されるはずである。周波数安定化技術が普及す れば，このようなコヒーレント加算によって出 力を増大することが広く行われるようになるだ ろう。なぜなら,このような方式の拡大則はシ
ンプルで線形だからで，エレクトロニクス技術 の拡大則と同じだからである。すなわち，大電 流の回路素子が必要なときに, レーザーのコヒー レント加算が可能になれば，標準品のトランジ ス夕を大量に並列動作させるように，“部品と してのレーザー発振器”ということが現実化で きる。このとき, 個々のレーザー発振器の発生 する雑音成分の内, 独立な原因による雑音は, コヒーレント加算されるにしたがって互いに打 ち消し合うので, 加算のビーム数を $N$ とすれば, 周波数雑音も $1 / \sqrt{N}$ 倍に減少するはずである。

\section{2 アクティブなコヒーレント加算}

同じ周波数に安定化されたレーザーを大量に コヒーレント加算すれば，どのような高出力も 得ることができる。しかし，個々のレーザーの 周波数を安定化するということと，お互いの周 波数をぴたりと合わせるということは同じでな く，はるかにむずかしい技術となる。これは個々 のレーザーが完全に独立の存在であるところに むずかしさがあるので，レーザー発振器の原理 の誘導放出のように，入射レーザーがその性質 をそっくり受け継ぐ子供を生むようにして増大 して行く方式を採用すれば，困難性は半減する だろう。独立したレーザー同士をこのような関 係にするのを注入ロック方式という。通常は小 さな入力で大きな出力を発生させるように制御 することが研究されているが, 周波数安定化レー ザーでは必ずしも注入ロック比を大きく取る必 要はない。むしろ，お互いを密に結合してコヒー レント加算の精度をあげることが重要なので, これまでとはまったく違う注入ロック方式を考 えることができる。

部品となったレーザー発振器を直並列に並べ, おのおのを密に結合した注入ロックまたは注入 チェーンを行う概念図をFig. 11に示した。親と なる安定化レーザーの出力はビームスプリッ夕 で2つに分けられ，おのおの同じ規格のレーザー 発振器に注入ロックされる。注入されるシード ビームの位相をスレーブ発振器の共振器に整合 させると，安定化された注入レーザー光は $100 \%$ 


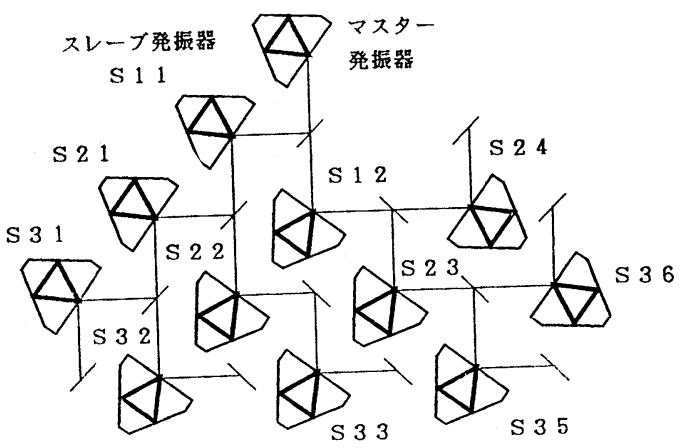

Fig. 11 Future image of high power lasers. Stabilization techniques make it possible to produce high power laser beams by means of coherent addition of outputs of transistor-like modules in a series-parallel injection chain arrangement.

スレーブ発振器の共振器に吸収される。本来発 振するパワーの $50 \%$ もの大きをを持った入力を 受けたスレーブ発振器は, 雑音から立ち上がる 通常のレーザーとは違って, ほとんど増幅器の ように忠実に注入レーザー光のエネルギーだけ を増大させて出力する。最初は 0.5 の入力に対 して1.5の出力を出す注入ロックだが，増幅， 分割を繰り返すにしたがって, 次第に入力 1 に 対して出力 2 を出すようになる。このように， 親が子供を作るようにしてレーザー出力を増大 した後，コヒーレント加算を行えば，元来同じ レーザーから発生した種を分割，増幅した訳な ので，お互いの周波数，位相関係は安定する。 お互いのレーザーの制御も, 注入ロック幅, 通 常数メガヘルツの周波数の幅では, 入射レー ザーと同じ周波数で出力するので，緩和される だろう。この図を見れば，レーザー技術もかな り電子回路技術に近づいたことが実感できるだ ろう。

\section{3 高性能光学素子の必要性}

コヒーレント加算では光源としてのレーザー の周波数，位相，コらには空間的性質まで完全 に揃えることが要求され，そちらだけで問題が 解決するような感じを与える。しかし，使用さ
れる光学素子，ミラーやビームスプリッ夕など の “パッシブな” 光学素子もまた, 高性能が要 求される。なぜなら，もし挿入される光学素子 に吸収，散乱などの損失があった場合，これら の損失は透過，反射の光ビームの位相を変化さ せて，結果として，完全なコヒーレント加算を することを妨げるからである。したがって，光 学素子もまた雑音源であると認識して，位相を 乱さない超低損失光学素子を開発することがど うしても必要となる。光を発生したり，増幅す る，または光の位相や周波数を変換するような アクティブな光学素子が雑音を発生することは 理解し易いが，ミラーのような静的で何もして いないように見える光学素子自身が雑音を生み 出すということは必ずしも広く認識されていな い。しかし，この問題は，光の性質を極限的に 追求するときにはきわめて重要となる。ここで 論じているような応用，例えばコヒーレント加 算やその他の干渉性を利用した新しい応用は， その様な観点を不可欠のものとするだろう。同 時に, 重力波検出のような科学研究では, 一足 先にこのような基本的問題に直面して抢り，一 般応用研究のよき先達となろうとしている。

\section{6. 安定化レーザーによる高感度計測}

重力波検出は将来の課題としても，現状の安 定化レーザーで, 参照共振器の長さの極微少な 変化や共振器の傾きを高感度に測定することが できる。2台のレーザーを同一共振器にロック した場合，お互いに隣合うモードに固定されて いるので，共振器長がわずかにずれると，ビー 卜周波数に

$$
\frac{\mathrm{d} f_{\mathrm{b}}}{\nu_{\mathrm{FSR}}}=-\frac{\mathrm{d} L}{L}
$$

という関係で反映する。実験条件を適用すると， 共振器長 $L=203 \mathrm{~mm}$ が $1 \mathrm{~nm}$ 膨張すれば, ビート 周波数は3. $6 \mathrm{~Hz}$ 減少する。100 $\mathrm{mHz}$ オーダーま で計測できることから，0.1 nmの長さの変動を 計測できることが分かった。

振動の影響を測定するために，参照共振器の 
足場にPZTを取り付け，わずかに振動を加える 実験を行い, 共振器の傾きに対する検出感度を 測定した。共振器が傾くと, モード整合条件がわ ずかに変化し，横モードが発生するようになる。 このため, 与えた振動と同じ周波数成分の誤差 信号が得られた。誤差信号と傾きの関係を示し たものがFig. 12で, 最小検出感度は $10^{-10} \mathrm{rad}$ 達することが分かった。これは $1000 \mathrm{~km}$ に対し て，わずか $0.1 \mathrm{~mm}$ の変位が与える傾きの大きさ である。

\section{7. 固体レーザーのスケーリング則}

重力波天文学の要求は出力に対しても途輬も なく厳しい。出力 $1 \mathrm{~kW}$ 以上で縦横単一モード, しかもその量子限界まで周波数を安定化させよ, というものであるから, 従来の技術の延長でで きる課題ではない。現時点では, 本当に可能か どうか分からない。しかし，もし可能だとすれ ば, その方式は, コヒーレントなLDでなくて はできない新しい励起方式 ${ }^{10)}$ があるべきだろう。 新しい励起方式を考案するために, 基礎的な拡 大則から検討しょう。

高出力レーザーの最終的な限界を決定するも のは熱的拡大則である。光励起レーザーの熱的

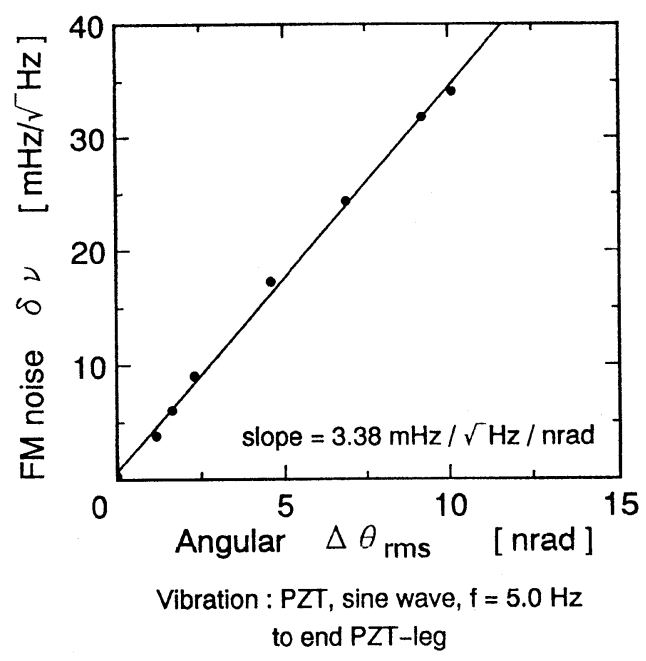

Fig. 12 Frequency stabilized lasers can measure the tilting angle of $10^{-10} \mathrm{rad}$.
拡大則を簡単に検討すると，すべての熱は結晶 表面を通じて散逸されるので, 吸収体積 vs表面 積の比率で冷却能力が決定される。端面冷却, 側面冷却の各々について体積／表面積を検討す ると,

端面冷却の場合 $\frac{V}{S}=\frac{\pi b^{2} L}{\pi b^{2}}=L$

側面冷却の場合 $\frac{V}{S}=\frac{\pi b^{2} L}{2 \pi b L}=\frac{b}{2}=\frac{\sqrt{V}}{2 \sqrt{\pi L}}$

となる。ただし，端面冷却は1端面からの冷却 とし, $b$ はロッドの半径, $L$ は長さである。冷却 能力の拡大則の意味するところは, 端面冷却の 場合，長さが短ければ短いほど，冷却能力が大 きくなるということで，一方，側面冷却では半 径が小さければ小さいほど良い。もし，一定の 励起体積を考えれば，冷却能力の点からいえば, きわめて薄い薄膜状のレーザー媒質を端面冷却 する方式と，きわめて細いロッドを側面から冷 却する方式が，もっとも多くの励起入力を許容 するということである。これを励起吸収の観点 から云えば, 前者はOptically Thickで, 後者は Optically Thinな条件の励起を行うことになる。 我々は実際にこの2つの極限を満足させるよう な固体レーザーの開発に取り組んでいる。 $\mathrm{YVO}_{4}$ アクティブミラーと仮想光源クラッド励 起YAGレーザーがそれである。以下では後者 に絞って，紹介する。

\section{1 仮想光源クラッド励起YAGレーザー}

アクティブミラーと対称的な方式として, 仮 想光源クラッド励起レーザーを考案した。すべ ての点でアクティブミラーと好対称をなす。結 晶形状としては, 高いアスペクト比の細長いロッ ドを用いる。励起方式は本質的に側面励起であ る。積極的に吸収係数の低い, 光学的に薄い (Optically Thin) レーザー媒質を用いることな どである。

\subsection{1 原理}

仮想光源クラッド励起方式の原理的な説明の ためにFig. 13を参考にしよう。本方式の特長を 

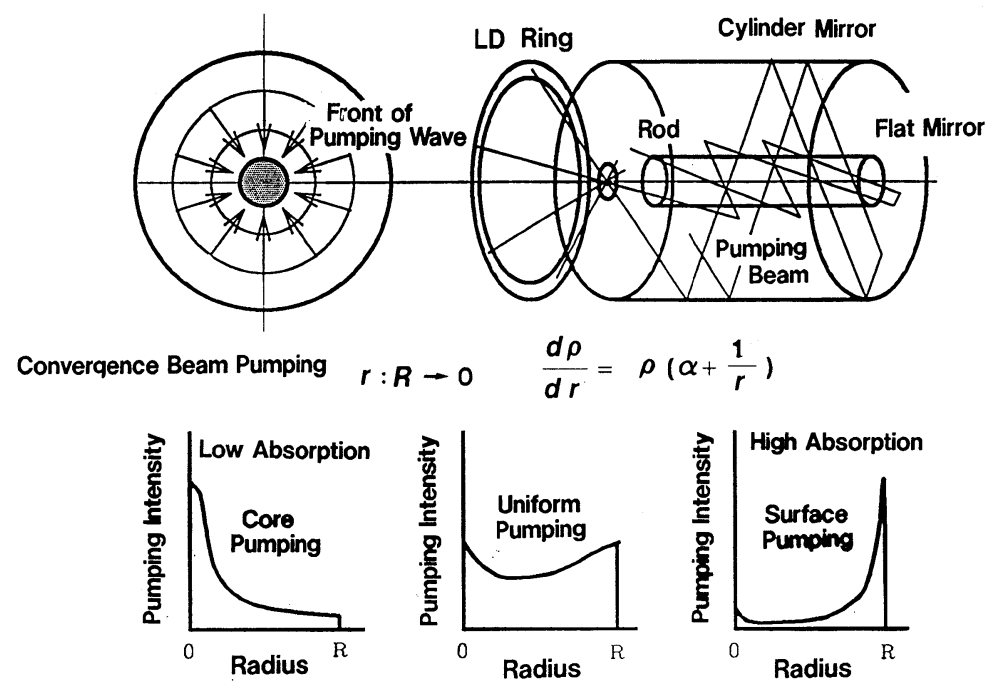

Fig. 13 Conceptual view of virtual source clad pumping scheme of solid state lasers.

列挙すると，

1) 半導体レーザーで一旦, 光軸上に仮想的光 源を形成し，円筒状反射鏡によって同軸側 面励起を行う。

2) 結晶の半径 $\times$ 吸収係数を小さく設定し，励 起光の収束性を励起分布に反映させ，中心 に集中したモード整合のよい励起分布を形 成する。

3) 同軸円筒における光軸上光学イメージの転 送により, 多重パス吸収を行い, 高い励起 効率を保持する。

などである。この方式では, 非常に細長い結晶 の中心に効果的に励起を行い，同時にアクティ ブミラー方式でも実験した利得誘導型の横モー ド制御を実現しようとする。Fig. 13の構成で， 円筒型反射鏡断面を考える。 $\mathrm{z}$ 軸方向の分布は 積分効果として働くと考え，原理的な考察から 外す。仮想的な光源の大きさを無視して点光源 を仮定すると, 収束励起ビームによる吸収過程 は,

$$
\frac{\mathrm{d} I}{\mathrm{~d} r}=\left(\alpha+\frac{1}{r}\right)
$$

と表現される。Iは励起光強度， $\alpha$ は吸収係数 である。収束ビームで励起する場合, 光は $r=R$ $\rightarrow 0$ と移動するので, 光強度は吸収されて減少 する効果と, 収束によって強度が高まる効果の 両者を含む。吸収方程式の解は

$$
I=I_{0} \frac{b}{r} \exp \left\{\alpha b\left(1-\frac{\mathrm{r}}{b}\right)\right\}
$$

となる。ここで分布を決定するのは， $\alpha b$ ，すな わちロッドの光学厚さ (Optical Thickness)であ ることを注意したい。円筒ミラーと光軸状の点 光源の組み合わせでは, 点光源は点イメージに 結像し，ロッドで吸収されなかった光はもう一 度反射して次の場所に点イメージを形成する。 完全同軸励起では全ての光はロッド衣面に兲直 に入射するので，多重パスを繰り返しても光源 像の転送特性が変化することはない。吸収係数 が飽和することはないので, 励起光強度分布は そのまま励起強度分布と一致する。

上で述べた原理は，吸収係数が非常に小さな レーザー材料やロッド半径が細い結晶を用いる と, 光収束の影響を表面化した励起分布を得る ことができて，そのときの励起効率は光源の性 
質さえよければ低下することはない，というこ とを示している。

\section{1 .2 励起分布の計算}

計算された励起分布の例はFig. 14の通りであ る。光源サイズが増大するにつれて, 吸収係数 の低い場合に，励起分布がガウス形状に近づく 様子が分かる。光源サイズをさらに大きくすれ ば均一分布に接近することは当然で，本方式は 均一分布からガウス分布まで, 仮想光源の大き さを調整することで変化させることができる。 したがって，与えられた共振器モードに整合さ せることも，LDの集光特性を調整すればでき るだろう。LDアレイなどのビーム重畳による 利得整形の試み ${ }^{11)} に$ 比べて, 格段とガウス形状 に近づいており，この方式の有利性が理解できる。

マルチビームのLDで励起する場合を考え， 光線追跡法で3次元解析を行い, 励起分布の実 際を計算することを試みた。3D光線追跡計算 には, 広がり角をもった励起ビーム, 軸外れの 収差の影響, ロッド表面での屈折, ビーム偏向, 円筒反射鏡の表面損失, その他の単純なモデル では考慮しなかった要素を含ませて, 単純モデ ルがどこまで適用可能かをチェックした。計算 結果の一例をFig. 14に示す。仮想光源の光源内 強度分布を均一やガウス形状に変化させて, 単 純モデルの妥当性を検証した。本質的に同一の 結果が得られ, 単純なモデルでも問題ないこと が分かった。均一分布としてトップハット形状 を仮定したが, 光源内強度分布としてはガウス
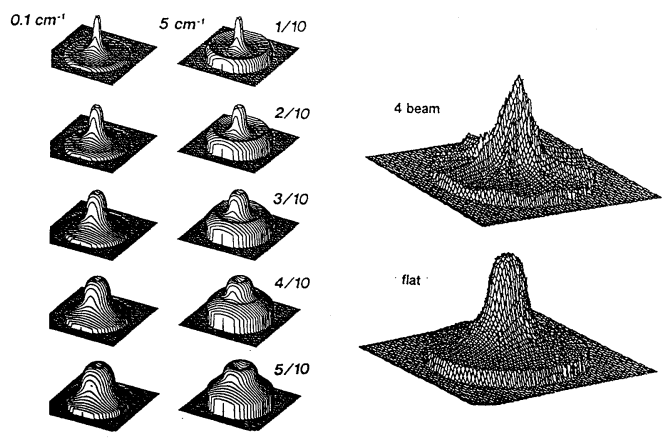

Fig. 14 Calculated pumping distribution.
型よりむしろトップハット分布の方が励起強度 分布としてよい結果を得た。ビーム数を32本に すると, LDが離散的に重畳されていることの 影響はまったく観測されなくなった。

\subsection{3 クラッド励起装置の試作}

実際に32本のLDビームで励起するための装 置を試作し, 実験を開始した。実際に試作した 仮想光源クラッド励起レーザーの断面図はFig. 15 の通りである。光軸上に一旦, 点または線光源 を形成する代わりに，ファイバー結合された $\mathrm{L}$ D出力を円錐ミラーで円筒キャビティーに導入 するようにした。この方式では $r \theta$ 平面では原 理と同様に収束ビーム励起となるが, $r z$ 平面内 では平行ビームとなるので都合がよい。仮想光 源の位置は必ずしもロッドの外部である必要は なく, 本方式では仮想光源はYAGロッド内に 形成される。

ロッドは $0.5 \%$ 濃度と薄いものを用い， ロッ ド直径は $2 \mathrm{~mm}$ である。したがって，すべての 励起光を吸収するには20パス程度必要となる。 本装置の入射角ではマルチパス吸収の回数は最 大10回でかなりの部分が吸収されずに損失とな るが, Optically Thinの状態で実験を行うため に，あえて試作をしてみた。ロッドの周辺は水 冷されており，LDは泠却水を通して励起する。 冷却水の屈折率の影響を受けないのも，すべて を同軸配置にし，励起光をロッドに垂直入射さ せている利点である。装置の外観はFig. 16の通 り, シンプルである。

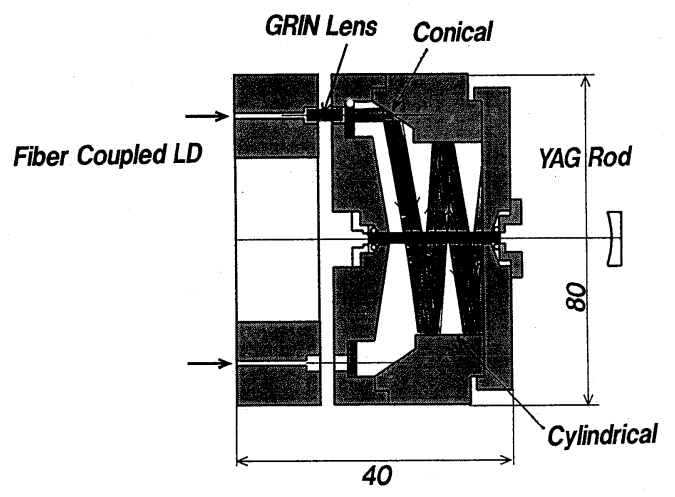

Fig. 15 Cross-sectional view of the VSCP laser head. 


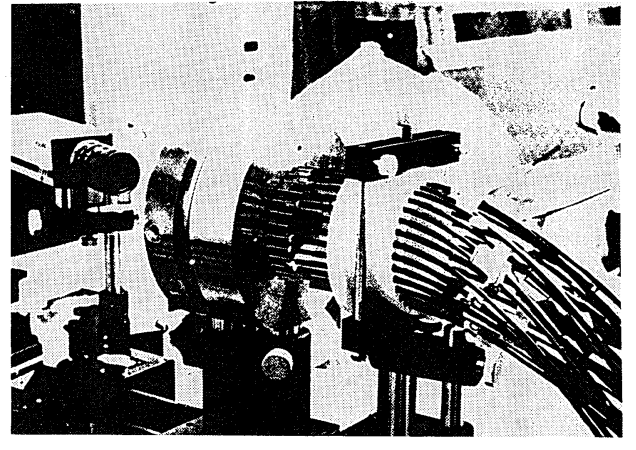

Fig. 16 Picture of outlook of the VSCP laser. Thirtytwo fibers transport the power of LDs into the pumping cavity.

\section{1 .4 励起分布の計測}

LDを入射するためのレンズとして,$f=5.4 \mathrm{~mm}$ のGRINレンズと $f=25 \mathrm{~mm}$ の平凸レンズを用い た。GRINレンズはファイバーとの結合効率が 高いが集光スポット径が大きく, 一方, 平凸レ ンズは集光スポット径が小さいが立体角が制限 され，LD光の一部しか取り达まない。しかし， 本実験ではレーザー共振器のモード体積と励起 体積の比較を行うために，あえてこの2種類の 条件で実験を行った。

1 パス励起の条件でロッドの発光分布を測定

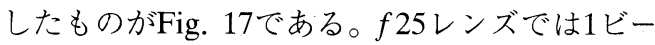
ム照射のビーム直径が 170 ミクロンとなり，端 面励起と同等の集光特性を示した。32ビームを 重ねると 310 ミロンと拡大する。一方, GRIN レンズによる集光では1ビームの励起分布で 690 ミクロンの幅をもち，32本を重ねると $1.97 \mathrm{~mm}$ とロッド全体に広がった励起が行われた。した

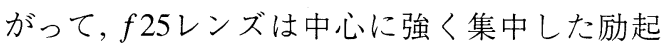
で，GRINレンズはロッド全体を使った励起が 効果的にされていることが判明した。今回の実 験では共振器のモード体積が直径 $2 \mathrm{~mm}$ 程度の 長大な共振器で実験できないが，両者はモード 体積と励起体積を比較する良い例となった。 $f 25$ レンズの結果は, 側面励起にもかかわらず, 1 ビーム励起では170ミクロンと, 端面励起と同 等の局所的励起ができることも明らかにした。

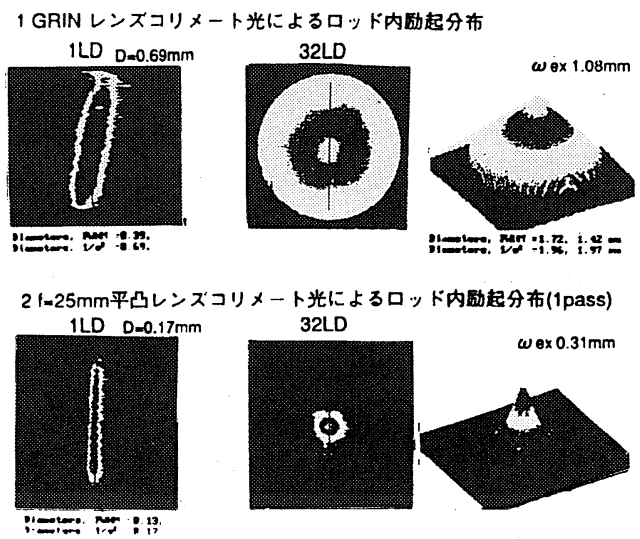

Fig. 17 Pumping distribution measured in a single pass excitation. The effective pumping width is 170 microns at the center.

\section{1 .5 発振モードの計測}

$r=1000 \mathrm{~mm}$ の凹面鏡を用いた平面一凹面光 共振器で，共振器長を $500 \mathrm{~mm}$ とした条件は，今 回の実験の中ではもっともモード体積が大きい。 モード体積の半径は $0.41 \mathrm{~mm}$ あ゙あ。このとき の発振特性をFig. 18に示した。両者とも，すべ ての励起条件において TEM 00 単一モード発振を した。そのときのモードパターンをFig. 19に示 す。高出力でも完全な単一横モード発振をして

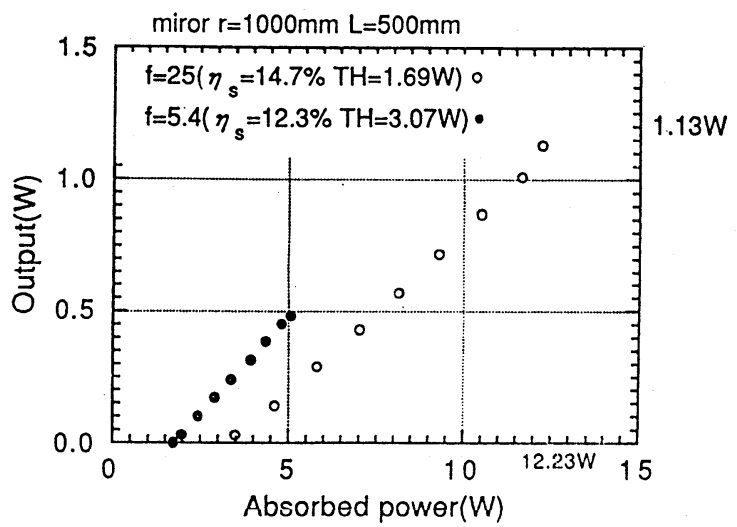

Fig. 18 Output characteristics for $\mathrm{TEM}_{00}$ mode operation. The focal length of collimating lenses is $25 \mathrm{~mm}$ for flat concave lenses and $5.4 \mathrm{~mm}$ for GRIN lenses, respectively. 


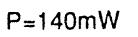

$720 \mathrm{~mW}$

(GRIN $r=1000 \mathrm{~mm} \mathrm{~L}=500 \mathrm{~mm}$ )
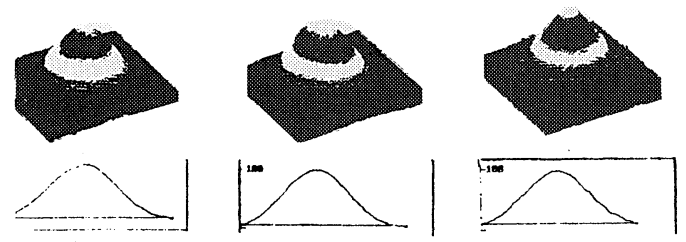

Fig. 19 Mode patterns of single transverse mode output using GRIN lens collimation.

いることが分かる。 $f 25$ レズの場合は, 励起 が中央部に集中するため, 中心部の利得係数が 高くなり, 発振しきい值はGRINレンズの場合 の半分である。

GRINレンズによる集光がロッド全体を励起 する形でガウス分布的な形状をしていることは 先に述べた。2種類の共焦点共振器条件におけ る発振特性を示したのがFig. 20である。モード 体積の小さなものはマルチモード化したのに対 して, $r=1000 \mathrm{~mm}$ でモード体積が比較的大き な条件では最後までTEM 00 モードであった。ロッ ド体積全体を有効に利用したマルチモード発振 の方がスロープ効率が高くなるのは自然である。 一方, 共振器長が短い方が回折損失が少ないの で，しきい值パワーが低い。実際，マルチモー ド発振に移行する様子を示したのがFig. 21であ り，330 mW出力までは単一モードであったも のが, 利得上昇に伴って大きな励起体積からエ

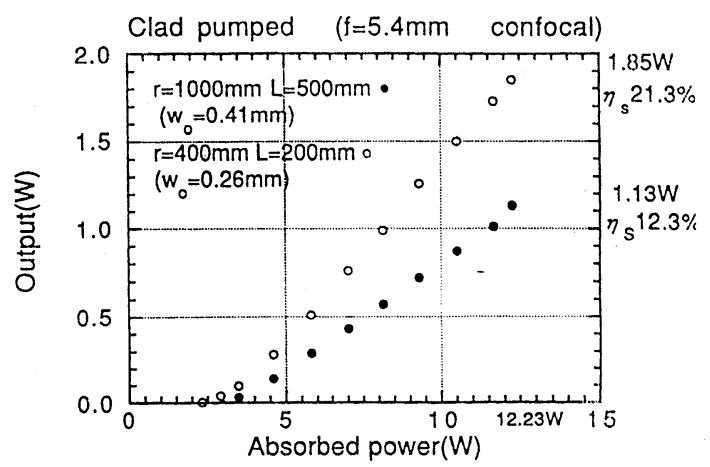

Fig. 20 Input/output characteristics of GRIN lens pumping.

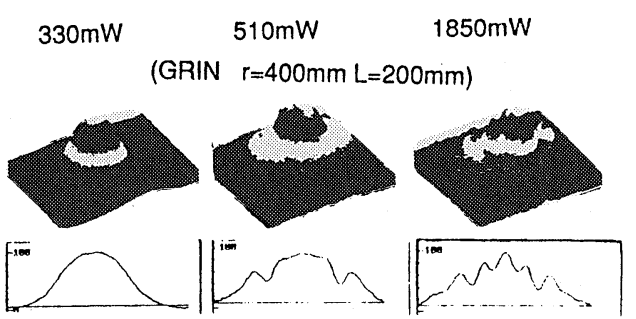

Fig. 21 Mode transition from single to multi-mode in a cavity of $200 \mathrm{~mm}$ length and $400 \mathrm{~mm}$ curvature. GRIN lenses were used for collimation of laser beams.

ネルギーを引き出すためにマルチモード化する 様子がはっきりと分かる。共振器長が $200 \mathrm{~mm}$ の場合には，単一横モードに対応するビームウェ スト半径は0. $26 \mathrm{~mm}$ であり，これらの共振器に よる差はモード整合条件によると結論できる。

\section{8. まとめ}

現在, わが国で進行中の重力波検出の研究を 例にして, 重力波検出用に要求される光学技術, レーザー技術を紹介した。真の意味で極限的な 計測である重力波検出は，同時にきわめて多く の技術的挑戦課題を抱えている。このように量 子限界に挑戦する応用では，レーザー技術の発 展なしには，解決が困難な問題がたくさんある。 一方, きわめて大きな飛躍が必要なために, 自 由な発想で研究を新たに見直す良い機会も提供 している。最後に示した仮想点光源クラッド励 起方式などでは，新しい発想に基づき，実験が 行われ, 現在, $320 \mathrm{~W}$ から $1 \mathrm{~kW}$ 高出力LDで 励起する新方式の固体レーザーが開発されつつ ある。学術分野の研究者のみならず, 広く産業 分野で活躍する研究者のご協力を扮願いする次 第である。なお，本研究は文部省科研費重点領 域研究「重力波天文学」の一環で, 計画研究 「高出力・高安定レーザーの開発」として行わ れている。 


$$
\text { 参 考 文 献 }
$$

1）重力波アンテナ技術検討書一千渉計ハンドブッ クー, 三尾典克, 大橋正健編 文部省科研費重点 領域研究「重力波天文学」，1992年10月.

2) 藤本真克, 大橋正健 : レーザー研究 19 (1991) 830.

3) D.Shoemaker, A.Brillet, C.Nary Man, O.Cregut, and G.Kerr : Opt. Lett. 14 (1989) 609.

4) R. Drever, J. Hall, et. al.. : Appl. Phys. B, 31 (1983) 97.

5) T. Kane and R. Byer: Opt. Lett. 10 (1985) 65.
6）上原昇，植田憲一：レーザー研究 21 (1993) 590.

7) N. Uehara and K. Ueda : Opt. Lett. 18 (1993) 505.

8) K. Ueda and N. Uehara : SPIE \& OSA to be published.

9) G. Rempe, R. J. Thompson, H. J. Kimble and R. Lalezari : Opt. Lett. 17 (1992) 363.

10) K. Ueda and N. Uehara : SPIE 1837 (1992) 336.

11) F. Brioschi, E. Nava and G. C. Reali : IEEE J. Quantum Electron. QE-28 (1992) 1070. 